Jurnal Mutiara Akuntansi Vol. 6, No.2 (Desember 2021) 201-214

ISSN 2579-7611 (Online) | http://u.lipi.go.id/1487661056

\title{
Budaya Organisasi, Komitmen Profesional, Dan Etika Auditor Terhadap Kinerja Auditor
}

\author{
Vindi Slamet Sesari ${ }^{1}$, Ahmad Mukoffi², Hermi Sularsih3 ${ }^{*}$, Fidyah Arini \\ Kusuma Wardhani ${ }^{4}$ \\ Prodi Akuntansi, Sekolah Tinggi Ilmu Ekonomi Gempol; Universitas Tribhuwana \\ Tunggadewi Malang \\ Jl. Raya Timur Pasar. No.9 Gempol-Pasuruan, Jawa Timur 67155 \\ *E-mail Korespondensi: hermisularsihstieg@gmail.com
}

\begin{abstract}
This study aims to examine the effect of organizational culture, professional commitment, and auditor ethics on the performance of auditors at the Surabaya public accounting firm. The type of research conducted is descriptive quantitative research with survey method. The number of respondents in this study were 60 respondents from 12 Public Accounting Firms in Surabaya which were selected randomly. The method of data acquisition comes from questionnaires that are distributed directly to respondents. The data analysis technique used multiple linear regression analysis and hypothesis testing using the determinant coefficient test, $t$-test, and f-test. The results of the study indicate that organizational culture, professional commitment, and auditor ethics have a significant influence on auditor performance.
\end{abstract}

Keywords: Organizational Culture, Professional Commitment, Auditor Ethics, Auditor Performance.

\begin{abstract}
Abstrak
Penelitian ini bertujuan untuk menguji pengaruh budaya organisasi, komitmen professional, dan etika auditor, terhadap kinerja auditor pada kantor akuntan publik Surabaya. Jenis penelitian yang dilakukan adalah penelitian deskriptif kuantitatif dengan metode survei. Jumlah responden dalam penelitian ini adalah 60 responden dari 12 Kantor Akuntan Publik di Surabaya yang dipilih secara acak. Metode perolehan data berasal dari kuesioner yang dibagikan secara langsung kepada responden. Teknik analisis data menggunakan analisis regresi linear berganda dan uji hipotesis menggunakan uji koefisien determinan, uji-t, dan uji-f. Hasil penelitian menunjukkan bahwa budaya organisasi, komitmen professional, dan etika auditor memiliki pengaruh yang signifikan terhadap kinerja auditor.
\end{abstract}

Kata kunci:Budaya Organisasi, Komitmen Professional, Etika Auditor, Kinerja Auditor.

doi: https://doi.org/10.51544/jma.v6i2.2420

(C) 2021 Jurnal Mutiara Akuntansi. This is an open access article under the CC BY-SA license Website: http://e-journal.sari-mutiara.ac.id/index.php/JMA/

http://e-journal.sari-mutiara.ac.id 


\section{PENDAHULUAN}

Kinerja adalah hasil karya yang dicapai oleh seseorang dalam melaksanakan tugas-tugas yang dibebankan kepadanya, Hasil ini dicapai berdasarkan atas kecakapan, pengalaman, dan kesungguhan waktu yang diukur mempertimbangkan kuantitas, kualitas, dan ketepatan waktu, Kinerja auditor merupakan perwujudan kerja dalam mencapai hasil kerja yang lebih baik dalam mencapai tujuan organisasi, Kinerja auditor merupakan hasil yang diperoleh seorang akuntan publik yang menjalankan tugasnya secara objektif dan independen atas laporan keuangan suatu perusahaan atau organisasi, untuk melihat apakah laporan keuangan tersebut sudah sesuai dengan prinsip-prinsip akuntansi(Hanna and Firnanti 2013).

Namun saat ini kepercayaan masyarakat terhadap kinerja profesi auditor mulai banyak dipertanyakan dalam hal memeriksa dan menilai laporan suatu perusahaan. Hal ini didukung oleh bukti yang semakin banyaknya fenomena kinerja auditor yang menurun dalam hal pemeriksaan ataupun penilaian kepada perusahaan sebagai audit, seperti adanya kasus pada tanggal 29 Mei 2015 Sekretaris Jenderal Keuangan mengatas namakan Menteri Keuangan Republik Indonesia mengeluarkan surat Keputusan Menteri Keuangan Republik Indonesia No. 445/KM.1/2015 tentang pembekuan izin akuntan publik Ben Ardi, CPA selama 6 bulan. Berdasarkan hasil pemeriksaan yang dilakukan oleh tim Pusat Pembinaan Profesi Keuangan (PPPK) terhadap 2 Akuntan Publik Ben Ardi, CPA dari Kantor Akuntan Publik Jamaludin, Ardi, Sukinto, dan Rekan disimpulkan bahwa Akuntan Publik Ben Ardi, CPA belum sepenuhnya mematuhi Standar Audit (SA)-SPAP dalam pelaksanaan audit umum atas laporan keuangan PT. Bumi Citra Permai, Tbk. Tahun Buku 2013. Ketidakpatuhan merupakan pelanggaran terhadap ketentuan Pasal 25 ayat (2) huruf b UU No. 5 tahun 2011 tentang akuntan publik yaitu mematuhi dan melaksanakan SPAP dan kode etik profesi, serta peraturan perundangundangan yang berkaitan dengan jasa yang diberikan. Ketidakpatuhan dikategorikan sebagai pelanggaran berat karena berpotensi berpengaruh cukup signifikan terhadap laporan auditor independen. Selama pembekuan izin, akuntan publik Ben Ardi, CPA dilarang memberikan jasa audit, dilarang menjadi pemimpin KAP maupun pemimpin cabang KAP, dan harus tetap bertanggung jawab terhadap jasa yang diberikan (pppk.kemenkeu.go.id | Senin, 7 September 2015 | 12:10:24 PM).

Dari kasus diatas menunjukan bahwa kinerja auditor dalam proses pemeriksaan ataupun penilaian untuk pihak yang berkepentingan masih jauh dari kata baik. Hal ini dikarenakan tidak diterapkannya prinsip objektifitas, masih kurangnya auditor untuk memahami prosedur auditor yang telah ada. Karena seorang auditor harus mampu mengungkapkan, mendeteksi, dan mahir dalam membaca laporan keuangan yang ada agar dapat mendeteksi kecurangankecurangan yang terjadi dalam perusahaan. Oleh karena itu kinerja auditor harus lebih ditingkatkan karena begitu pentingnya peran Kantor Akuntan Publik dalam bisnis maupun bagi publik dalam menilai hasil 4 audit yang dilakukan dan profesi auditor sangatlah bertanggung jawab dalam laporan keuangan sehingga diperlukan faktor yang akan membantu peningkatan kinerja seorang auditor seperti budaya organisasi, komitmen profesional dan etika seorang auditor terhadap kinerja seorang auditor.

Budaya organisasi adalah sebuah karakteristik yang sangat dijunjung tinggi oleh organisasi dan yang menjadi panutan dalam organisasi sebagai pembeda antara satu organisasi dengan organisasi yang lain, atau budaya 
organisasi juga diartikan sebagai nilai-nilai dan norma perilaku yang diterima dan dipahami secara bersama oleh anggota organisasi sebagai dasar dalam aturan perilaku yang terdapat dalam organisasi tersebut (Nugraheni, 2016), beberapa atribut ini budaya yang tapi satu aspek kunci dari budaya perusahaan tidak terlihat (McInnes et terlihat al., 2013), Budaya menggabungkan aturan tidak tertulis, asumsi tentang perilaku yang diharapkan, gaya dan sikap yang terbentuk dari budaya nasional, dan ortodoksi atau moralitas dalam masyarakat dan lingkungan yang mengelilingi organisasi dan dari mana sebagian besar karyawan datang berlaku (Nugraheni, 2016).

Hal tersebut semakin diperkuat dengan adanya beberapa hasil peneliti yang mengatakan bahwa budaya organisasi memiliki pengaruh positif terhadap kinerja auditor (Hartidah and Ludigdo 2010; Safitri 2014; Sitio and Anisykurlillah 2014; Trisnaningsih 2007; Wonosardono 2018). Selain budaya organisasi komitmen profesional juga bepengaruh terhadap kinerja auditor. Sikap komitmen profesional merupakan suatu hal yang penting bagi seorang akuntan untuk mempertahankan profesionalismenya. Dalam menjalankan tugasnya, akuntan sering dihadapkan dengan dilema etis. Dilema etis merupakan situasi yang dihadapi seseorang dimana ia harus mengambil keputusan tentang perilaku yang tepat yang harus dipertimbangkan oleh seorang auditor (Arens et al., 2014), Komitmen merupakan unsur penting dalam dunia kerja, dengan adanya komitmen dalam seseorang ia akan selalu melaksanakan tugas dengan bersungguh-sungguh dan bertanggungjawab, menaati segala norma aturan dan juga kode etik profesi (Pangesti, S.N., Rahayu 2017). Didalam hasil penelitian (Pangesti, S.N., Rahayu 2017), mengatakan bahwa komitmen profesional sangat berpengaruh signifikan terhadap kinerja seorang auditor, dan ada beberapa peneliti juga mengatakan hal yang sama seperti di dalam hasil penelitian (Pratama and Latrini 2016; Halim 2014; Arifah and Romadhon 2015; Kusumastuti 2008; Widarsono and Oktarina 2015; Mukoffi, A. 2019), yang di dalam hasil penelitiannya juga mengatakan bahwa komitmen profesional seorang auditor sangat berpengarauh signifikan terhadap kinerja seorang auditor. Banyak faktor yang menyebabkan kinerja auditor menjadi turun, salah satunya yaitu kurangnya etika profesi dalam diri auditor. Hal ini didukung oleh teori menurut (Halim 2015) yang mengatakan bahwa etika profesi merupakan standar sikap para anggota profesi yang dirancang agar praktis dan realistis, tetapi tetap sedapat mungkin idealistis. Tuntutan etika profesi harus diatas hukum tetapi dibawah standar ideal (absolut) agar etika tersebut mempunyai arti dan berfungsi sebagaimana mestinya. Pernyataan ini diperkuat dengan penelitian terdahulu dilakukan oleh (Nugraha and Ramantha 2015) menunjukan bahwa semakin tinggi rasa patuh auditor terhadap etika profesi, maka kinerja auditor akan meningkat dan sebaliknya jika rasa patuh auditor terhadap etika profesi rendah maka kinerja auditor akan menurun.

\section{TINJAUAN LITERATUR}

\section{Kinerja Auditor}

Menurut (Choiriah 2013) Kinerja Auditor merupakan tindakan atau pelaksanaan tugas pemeriksaan yang telah diselesaikan oleh auditor dalam waktu tertentu. Penelitian yang dilakukan (Choiriah 2013) menyebutkan bahwa Kinerja Auditor adalah hasil kerja yang bisa dicapai oleh auditor sesuai dengan kemampuan yang dimiliki, komitmen akan pekerjaannya serta motivasi sebagai tolak ukur untuk mengukur kepuasan kerja masingmasing auditor. 


\section{Budaya Organisasi}

Budaya organisasi adalah nilai-nilai yang dianggap penting dan diyakini kebenarannya oleh setiap anggota perusahaan untuk digunakan dalam memecahkan masalah eksternal maupun internal yang terjadi dalam perusahaan itu sendiri. Budaya organisasi merupakan falsafah yang diciptakan oleh pendiri perusahaan dan kemudian dikembangkan untuk dijadikan pegangan dalam bersikap dan bertindak bagi seluruh karyawan. Hal ini sesuai dengan pendapat parah ahli : Menurut Wibowo (2013: 17) bahwa "budaya organisasi adalah nilainilai dan norma-norma bersama yang terdapat dalam suatu organisasi dan mengajarkan pada pekerja yang datang". Definisi ini menganjurkan bahwa budaya organisasi menyangkut keyakinan dan perasaan bersama, keteraturan dalam perilaku dan proses historis untuk meneruskan nilai - nilai dan norma - norma.

\section{Komitmen Profesional}

Komitmen Profesional Komitmen auditor terhadap profesinya merupakan faktor penting yang bepengaruh terhadap perilaku auditor dalam melakukan tugas audit. Tranggono dan Kartika (2008) menjelaskan komitmen profesional merupakan tingkat loyalitas individu pada profesinya seperti yang dipersepsikan oleh individu.

\section{Etika Auditor}

Menurut (Bambang, 2008), "etik merupakan suatu prinsip moral dan perbuatan yang menjadi landasan bertindaknya seseorang sehingga apa yang dilakukannya dipandang oleh masyarakat sebagai perbuatan yang terpuji dan menungkatkan martabat dan kehormatan seseorang." (HP \& Payamta, 2002) menyatakan bahwa berdasarkan "Pedoman Etika" IFAC, maka syarat-syarat etika suatu organisasi akuntan sebaiknya didasarkan pada prinsip-prinsip dasar yang mengatur tindakan/perilaku seorang akuntan dalam melaksanakan tugas profesionalnya.

Prinsip tersebut adalah (1) integritas, (2) objektifitas, (3) independen, (4) kepercayaan, (5) kemampuan professional, dan (6) perilaku etika. Kode etik auditor merupakan aturan perilaku auditor sesuai dengan tuntutan profesi dan organisasi serta standar audit yang merupakan ukuran mutu minimal yang harus dicapai oleh auditor dalam melaksanakan tugas auditnya, apabila aturan ini tidak dapat dipenuhi maka auditor tersebut bekerja dibawah standar dan dapat dianggap melakukan mal praktek (Nungky Nurmalita Sari, 2011) Pada dasarnya setiap individu yang melakukan pekerjaan akan mendapatkan kepercayaan dari pihak lain agar dapat mendukung kelancaran pekerjaan yang dilakukan. Setiap individu berkewajiban untuk menjaga kepercayaan yang telah diberikan dengan berbuat dan bertingkah laku sesuai dengan aturan yang ada dan memperhatikan kepentingan masyarakat yang berhubungan dengan pekerjaannya, supaya kepercayaan tersebut dapat terus terjaga (Primaraharjo and Handoko 2011). 


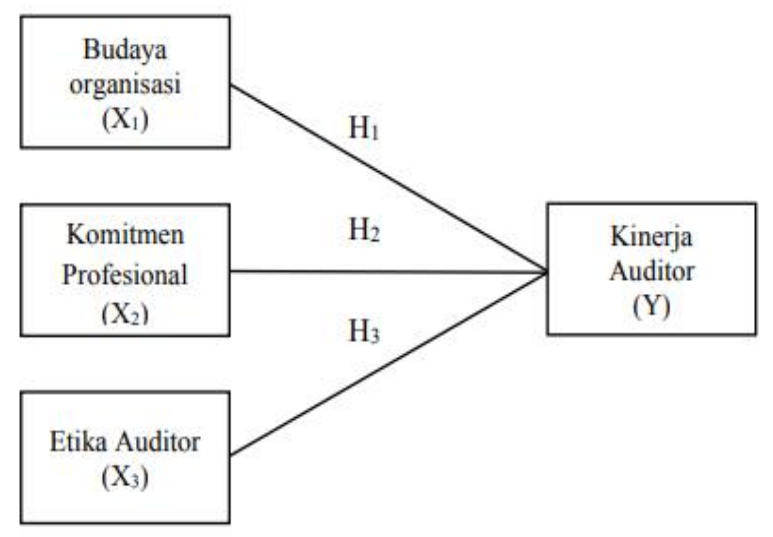

Gambar 1. Kerangka Konseptual

\section{METODE PENELITIAN}

Penelitian ini menggunakan metode deskriptif yang bersifat kuantitatif karena penelitian ini berkaitan dengan objek penelitian yaitu mengumpulkan data dan informasi yang berkaitan dengan Budaya Organisasi, Komitmen Profesional, Dan Etika Auditor Terhadap Kinerja Auditor disesuaikan dengan tujuan penelitian.

\section{Operasional Variabel Penelitian}

Variabel dalam penelitian ini terdiri dari variabel independen (bebas) dan variabel dependen (terikat) dengan definisi operasional variabel sebagai berikut:

\section{Variabel Independen $(\mathbf{X})$}

\section{Budaya Organisasi (X1)}

menurut (Robins 2014) menyatakan bahwa budaya organisasi adalah suatu pola asumsi dasar yang diciptakan oleh organisasi sebagai pembelajaran untuk memecahkan masalah adaptasi lingkungan eksternal dan integrasi internal serta dapat terlaksana dengan baik.

Komitmen Profesional (X2)

Profesional Komitmen profesional pada dasarnya merupakan persepsi yang berintikan loyalitas, tekad dan harapan seseorang dengan dituntun oleh sistem nilai atau norma yang akan mengarahkan orang tersebut untuk bertindak atau bekerja sesuai prosedur-prosedur tertentu dalam upaya menjalankan tugasnya dengan tingkat keberhasilan yang tinggi (Tafqihan and Suryanto 2014).

Etika Auditor (X3)

Menurut (Entuu, Sondakh, and Ilat 2013) etika profesi auditor yaitu "Etika Profesi Auditor adalah sebuah profesi harus memiliki komitmen moral yang tinggi dalam bentuk aturan khusus. Aturan ini merupakan aturan main dalam menjalankan atau mengemban profesi tersebut, yang biasa disebut kode etik".

\section{Variabel Dependen (Y)}

\section{Kinerja Auditor (Y)}

Menurut Malayu S.P.(Hasibuan, 2011 ;94) merupakan prestasi kerja yaitu sebagai berikut: "Suatu hasil yang dicapai seseorang dalam melaksanakan tugastugas yang diberikan kepadanya yang didasarkan atas kecakapan, pengalaman dan kesungguhan serta waktu". 


\section{Jenis Dan Sumber Data}

Dalam penelitian ini data yang digunakan adalah data sekunder, yaitu data primer yang diperoleh dari berbagai sumber yang telah ada dan kembali diolah lagi oleh peneliti. Data penelitian ini adalah data kuantitatif dimana data yang diukur dalam skala angka yang mewakili nilai variabel.

\section{Populasi Dan Sampel Penelitian}

Metode penelitian sampel menggunakan Metode Purposive Random Sampling, yaitu: teknik penentuan sampel dengan mempertimbangkan karakter dan ciri-ciri yang telah ditentukan terlebih dahulu untuk membatasi sampel (Sugiyono 2013), dengan tujuan untuk menunjukan bahwa responden merupakan benar-benar seorang auditor. .Populasi dalam penelitian ini adalah auditor yang bekerja pada KAP di Wilayah Jawa Timur khususnya untuk kota dan Surabya sedangkan sampel yang akan digunakan dalam penelitian ini adalah 60 responden.

\section{Teknik Analisis Data}

Metode analisis data adalah cara mendeskripsikan metode analisis apa yang akan digunakan oleh peneliti untuk meganalisis data yang telah dikumpulkan termasuk mengujinya. Bedasarkan identifikasi dan rumusan masalah serta tujuan penelitian, maka analisis data yang digunakan dalam penelitian ini adalah:

\section{Uji Asumsi Klasik}

Pengujian persamaan regresi berganda harus memenuhi persyaratan uji asumsi klasik, yaitu bahwa pengambilan keputusan melalui uji t dan uji $\mathrm{F}$ tidak boleh bias. Asumsi klasik ini bermaksud untuk memastikan bahwa model yang diperoleh benar-benar memenuhi asumsi dasar dalam analisis regresi yang meliputi asumsi: terjadi normalitas, tidak terjadi multikolinearitas, tidak terjadi autokolerasi dan tidak terjadi heteroskedastisitas.

\section{Uji Normalitas}

Uji normalitas merupakan pengujian yang dilakukan untuk mengetahui apakah dalam model regresi, variabel independen, dan variabel dependen memiliki distribusi normal (Ghozali,2016:154). Pengujian normalitas dalam penelitian ini dideteksi dengan metode analisis statistik uji Kolmogorov-Smirnov. Analisis statistiknya dilakukan dengan melihat nilai signifikan dari masing-masing variabel, apabila nilai signifikan $<=0,05$ berarti data residual tidak berdistribusi normal. Sebaliknya apabila nilai signifikan $>=0,05$ berarti data residual berdistribusi normal.

\section{Uji Multikolinearitas}

Uji multikolinearitas bertujuan untuk menguji apakah model regresi ditemukan adanya kolerasi diantara variabel independen (variabel bebas). Model regresi yang baik adalah tidak terjadinya korelasi diantara variabel-variabel independen tersebut. Untuk melihat nilai Variance Inflation Factor (VIF) dengan ketentuan, jika nilai VIF kurang dari 10, maka dapat disimpulkan bahwa tidak ada multikolinearitas antara variabel independen dalam model regresi (Ghozali, 2016:103).

\section{Uji Heteroskedastisitas}

Uji heteroskedastisitas bertujuan untuk mengetahui apakah dalam sebuah model regresi terjadi ketidaksamaan varians dari residual suatu pengamatan ke pengamatan lainnya. Analisis heteroskedastisitas dapat menggunakan grafik scatterplot. Apabila titik-titik tersebut tidak membentuk pola tertentu dan tersebar baik diatas atau dibawah angka nol pada sumbu Y, maka tidak terjadi heteroskedastisitas (Ghozali, 2016:134). Dalam penelitian ini Heteroskedastisitas diuji dengan menggunakan uji gleser dengan pengambilan keputusan jika variabel 
independen signifikan secara statistik mempengaruhi variabel dependen, maka ada indikasi terjadi heteroskedastisitas. Kriteria penilaian uji gleser yaitu jika probabilitas signifikan diatas tingkat kepercayaan 5\% $(0,05)$ maka model regresi ini tidak mengarah adanya heterokedastisitas.

\section{Uji Autokorelasi}

Uji autokorelasi bertujuan untuk menguji apakah dalam suatu model regresi linear ada kolerasi antara kesalahan pengganggu pada periode t dengan kesalahan pengganggu pada periode t-1. Penyebab timbulnya autokorelasi adalah karena kesalahan spesifikasi, misalnya terabaikannya suatu variabel penting atau bentuk fungsi yang tidak tepat (Ghozali, 2016:107). Untuk mendeteksi adanya gejala autokolerasi dapat dilakukan dengan uji run test dengan signifikansi harus lebih besar dari 0,05 .

\section{Analisis Regresi Berganda}

Penelitian ini menggunakan analisis regresi berganda bertujuan untuk menguji dan menganalisis, baik secara parsial maupun Pengaruh Budaya Organisasi, Komitmen Profesional, Dan Etika Auditor Terhadap Kinerja Auditordengan persamaan regresi berganda sebagai berikut:

$$
Y=a+b 1 X 1+b 2 X 2+b 3 X 3+e
$$

\section{HASIL DAN PEMBAHASAN}

\section{Hasil Analisis Regresi Linear Berganda}

Metode yang digunakan dalam penelitian ini adalah dengan menggunakan analisis regresi linear berganda. Analisis regresi linear berganda digunakan dikarena variabel dalam penelitian lebih dari satu. Penggunakan analisis regresi linear dimaksudkan untuk menentukan pengaruh variabel independen terhadap variabel dependen.

Tabel 1. Analisis Regresi Linear Berganda

\begin{tabular}{|c|c|c|c|}
\hline \multicolumn{4}{|c|}{ Coefficients $^{\mathrm{a}}$} \\
\hline \multirow{2}{*}{\multicolumn{2}{|c|}{ Model }} & \multicolumn{2}{|c|}{ Unstandardized Coefficients } \\
\hline & & $\mathrm{B}$ & Std. Error \\
\hline \multirow{4}{*}{1} & (Constant) & 3.169 & 1.438 \\
\hline & Budaya Organisasi & .706 & .101 \\
\hline & Komitmen Profesional & .362 & .089 \\
\hline & Etika Auditor & -.136 & .054 \\
\hline
\end{tabular}

Diperoleh persamaan regresi berganda sebagai berikut:

$\mathrm{Y}=3,169+0,7061+0,3622+(-136) 3+1,438$. 56 Hasil dari analisis tersebut dapat diinterpretasikan sebagai berikut:

1) Berdasarkan persamaan regresi diatas dapat diketahui bahwa nilai konstanta sebesar 3,169, menyatakan bahwa apabila variabel independen budaya organisasi (X1), komitmen professional (X2), dan etika auditor (X3) dianggap konstan, maka nilai variabel dependen yaitu kinerja auditor (Y) sebesar 3,169. 
2) Koefisien Regresi $X 1$ sebesar 0,706. Hasil ini menjelaskan bahwa variabel budaya organisasi (X1) mempengaruhi kinerja auditor (Y) sebesar 0,706. Artinya apabila setiap kenaikan nilai variabel budaya organisasi (X1) sebesar satu poin, maka akan meningkatkan kinerja auditor (Y) sebesar 0,706, dengan asumsi variabel yang lain tetap.

3) Koefisien Regresi X2 sebesar 0,362. Hasil ini menunjukkan bahwa variabel komitmen profesional (X2) memberikan pengaruh pada kinerja auditor (Y) sebesar 0,362. Artinya apabila setiap kenaikan nilai variabel komitmen professional (X2) sebesar satu poin, maka akan meningkatkan kinerja auditor (Y) sebesar 0,362, dengan asumsi variabel yang lain tetap.

4) Koefisien Regresi $X 3$ sebesar -0,136. Hasil ini menunjukkan bahwa variabel etika auditor (X2) memberikan pengaruh pada kinerja auditor (Y) sebesar -0,136.

Artinya apabila setiap kenaikan nilai variabel etika auditor (X3) sebesar satu poin, maka nilai kinerja auditor (Y) akan mengalami penurunan sebesar 0,136, dengan asumsi variabel yang lain tetap atau konstan.

Tabel 2. Pengujian Secara Parsial (Uji t)

\begin{tabular}{|c|c|c|c|c|c|c|}
\hline \multicolumn{7}{|c|}{ Coefficients $^{a}$} \\
\hline \multirow{3}{*}{\multicolumn{2}{|c|}{ Model }} & Unstandardized & Coefficients & Standardized & $t$ & Sig. \\
\hline & & & & Coefficients & & \\
\hline & & $B$ & Std. Error & Beta & & \\
\hline \multirow{4}{*}{1} & (Constant) & 3.169 & 1.438 & & 2.203 & .032 \\
\hline & Budaya Organisasi & .706 & .101 & .608 & 6.982 & .000 \\
\hline & Komitmen Profesional & .362 & .089 & .352 & 4.070 & .000 \\
\hline & Etika Auditor & -.136 & .054 & -.146 & -2.493 & .016 \\
\hline
\end{tabular}

a. Dependent Variable: Kinerja Auditor

Sumber: Data primer diolah, 2021

1. Uji Hipotesis 1 Untuk menguji hipotesis pertama yang menyatakan bahwa budaya organisasi berpengaruh signifikan terhadap kinerja auditor menggunakan uji t. Hasil uji t menunjukkan variabel budaya organisasi diperoleh nilai thitung 6,982 sedangkan nilai ttabel $=2,003$ dan nilai probabilitas $0,000<0,05$, jadi $\mathrm{H} 1$ diterima. Sehingga berdasarkan hasil tersebut terbukti variabel budaya organisasi (X1) berpengaruh secara signifikan terhadap kinerja auditor (Y). Dengan demikian hipotesis pertama secara statistik diterima.

2. Uji Hipotesis 2 Untuk menguji hipotesis kedua yang menyatakan bahwa komitmen profesional berpengaruh signifikan terhadap kinerja auditor menggunakan uji t. Hasil uji $t$ menunjukkan variabel komitmen profesional diperoleh nilai thitung 4,070 sedangkan nilai ttabel $=2,003$ dan nilai probabilitas $0,000<0,05$, jadi $\mathrm{H} 2$ diterima. Sehingga berdasarkan hasil tersebut terbukti bahwa variabel komitmen profesional (X2) berpengaruh signifikan terhadap kinerja auditor (Y). Dengan demikian hipotesis kedua secara statistik diterima.

3. Uji Hipotesis 3 Untuk menguji hipotesis ketiga yang menyatakan bahwa etika auditor berpengaruh signifikan terhadap kinerja auditor menggunakan uji t. Hasil uji t menunjukkan variabel etika auditor 
diperoleh nilai thitung -2.493 sedangkan nilai ttabel $=2,003$ dan nilai probabilitas $0,016<0,05$, jadi $\mathrm{H} 3$ diterima.

Sehingga berdasarkan hasil tersebut terbukti bahwa variabel etika auditor (X3) berpengaruh signifikan terhadap kinerja auditor (Y). Dengan demikian hipotesis ketiga secara statistik diterima.

\section{Hasil Uji Simultan (Uji-f)}

Uji F dilakukan untuk menguji apakah model yang digunakan dalam penelitian ini adalah model yang layak atau tidak. Uji F bertujuan untuk mengetahui apakah variabel independen secara simultan (bersama-sama) berpengaruh signifikan terhadap variabel dependen. Berikut hasil uji f :

Tabel 3. Pengujian Secara Simultan (Uji F)

\begin{tabular}{rrrrrrr}
\hline \multicolumn{7}{c}{ ANOVA $^{\mathrm{a}}$} \\
\hline Model & Sum of Squares & df & Mean Square & F & Sig. \\
& Regression & 282.029 & 3 & 94.010 & 80.125 & $.000^{\mathrm{b}}$ \\
1 & Residual & 65.704 & 56 & 1.173 & & \\
& Total & 347.733 & 59 & &
\end{tabular}

a. Dependent Variable: Kinerja Auditor

a. Predictors: (Constant), Etika Auditor, Komitmen Profesional, Budaya Organisasi

Sumber: Data primer diolah, 2021

Nilai f sebesar 80,125 dengan tingkat signifikansi 0,000. Hal ini menunjukan bahwa variabel independen yaitu budaya organisasi (x1), komitmen professional (x2), dan etika auditor (x3) secara simultan berpengaruh terhadap variabel dependen yaitu kinerja auditor (y). Sehingga model yang digunakan dalam penelitian ini adalah model yang baik.

\section{Pembahasan}

Pengaruh Budaya Organisasi Terhadap Kinerja Auditor Pada Kantor Akuntan Publik Di Surabaya.Berdasarkan hasil uji statistik menunjukkan bahwa budaya organisasi berpengaruh signifikan terhadap kinerja auditor pada kantor akuntan publik di Surabaya, artinya dengan adanya budaya organisasi yang baik maka dapat meningkatkan kinerja auditor. Budaya organisasi merupakan pola pemikiran dan tindakan yang mencerminkan nilai-nilai yang diakui serta menjadi pedoman dalam suatu organisasi. Budaya organisasi dapat menjadi kekuatan positif dalam mencapai prestasi organisasi yang efektif. Sehingga dengan adanya budaya organisasi dapat dijadikan pedoman bagi anggota organisasi. Hasil penelitian ini sejalan dengan penelitian yang dilakukan oleh Hartidah \& Ludigdo (2010), Hanna \& Firnanti (2013), Prabayanthi \& Widhiyani (2018), dan Temaja \&Utama (2016) yang menyatakan budaya organisasi berpengaruh signifikan terhadap kinerja auditor. Hal ini menunjukkan bahwa semakin tinggi budaya organisasi yang dimiliki oleh seorang auditor, maka semakin tinggi pula kinerja auditor yang dihasilkan.

Pengaruh Komitmen Profesional Terhadap Kinerja Auditor Pada Kantor Akuntan Publik Di Surabaya.Hasil uji statistik menunjukkan bahwa komitmen profesional berpengaruh signifikan terhadap kinerja auditor pada kantor akuntan publik di Surabaya, artinya sikap berkomitmen secara profesional dapat 
berpengaruh dalam memberikan perubahan yang berarti terhadap kinerja auditor yang berarti mengutamakan kepentingan publik di atas kepentingan manajemen atau kepentingan auditor itu sendiri. Hasil penelitian ini sesuai dengan penelitian Candra et al (2015) dalam penelitiannya menyatakan keberhasilan seseorang auditor dalam meningkatkan kinerjanya dipengaruhi secara positif oleh komitmen profesionalisme dengan mendedikasikan hasil auditnya pada kepentingan klien dan keinginan tulus dalam membantu permasalahan yang dihadapi klien sehingga profesi tersebut dapat menjadi kepercayaan masyarakat. Kinerja auditor sendiri harus ditunjang dengan komitmen untuk mencapai tingkatan yang tertinggi, menilai secara kritis bukti audit serta mengambil keputusan audit berlandaskan keahlian auditing yang dimilikinya dan selalu meragukan dan mempertanyakan segala sesuatu yang dikemukakan oleh manajemen tanpa ada fakta atau asersi yang jelas (Emrinaldi dan Dwi, 2014). Hal ini didukung oleh penelitian yang dilakukan oleh Priesty \& Budiartha (2017), menyatakan bahwa komitmen profesional auditor memiliki pengaruh signifikan terhadap kinerja auditor.

Pengaruh Etika Auditor Terhadap Kinerja Auditor Pada Kantor Akuntan Publik Di Surabaya.Berdasarkan hasil uji statistic yang dilakukan menunjukkan bahwa etika auditor berpengaruh secara signifikan terhadap kinerja auditor pada kantor akuntan publik di Surabaya, artinya semakin tinggi rasa patuh seorang auditor terhadap etika profesi auditor, maka kinerja auditor akan meningkat.Etika seorang auditor sangat penting dalam menjalankan profesional akuntan. Dengan etika yang tinggi auditor merefleksikan sikapnya sebagai individu yang independen, berintegritas dan berobyektivitas tinggi serta bertanggung jawab, sehingga dapat diberikan kepercayaan dalam melaksanakan tugas profesionalnya. Etika profesi auditor akan mendukung dalam melaksanakan dan menyelesaikan tugas-tugasnya sehingga tingkat kesalahan semakin berkurang. Etika auditor dipandang sebagai faktor penting dalam melakukan pemeriksaan laporan keuangan karena etika auditor merupakan penguat kaidah prilaku sebagai pedoman yang harus dipenuhi dalam mengemban profesi. Penelitian ini sejalan dengan penelitan yang dilakukan Saufina (2020), Pramudyawati (2019), Zaenudin (2017), dan Cahyani et al (2015) yang menyatakan bahwa etika auditor berpengaruh positif dan signifikan terhadap kinerja auditor.

\section{KESIMPULAN}

Berdasarkan hasil data yang diperoleh dari analisis, maka kesimpulan yang dapat diambil dari penelitian ini adalah:

1. Budaya organisasi berpengaruh signifikan terhadap kinerja auditor pada kantor akuntan publik di Surabaya. Hal ini dibuktikan dengan hasil uji t statistik menunjukkan variabel budaya organisasi menghasilkan nilai signifikansi 0,000 lebih kecil dari 0,050, artinya variabel kinerja auditor dapat dipengaruhi oleh budaya organisasi. Sehingga dapat disimpulkan bahwa semakin baik budaya organisasi yang diterapkan maka kinerja dari auditor juga semakin baik.

2. Komitmen professional berpengaruh signifikan terhadap kinerja auditor pada kantor akuntan publik di Surabaya.. Hal ini dibuktikan dengan hasil uji t statistik menunjukkan variabel komitmen professional menghasilkan nilai signifikansi 0,000 lebih kecil dari 0,050, artinya variabel kinerja 
auditor dapat dipengaruhi oleh komitmen professional. Sehingga dapat disimpulkan bahwa semakin tinggi komitmen professional yang dianut seorang auditor, maka kinerjanya akan semakin baik.

3. Etika auditor berpengaruh signifikan terhadap kinerja auditor pada kantor akuntan publik di Surabaya.

Hal ini dibuktikan berdasarkan uji t statistik menunjukan variabel etika auditor menghasilkan nilai signifikansi 0,016 lebih kecil dari 0,050, artinya variabel kinerja auditor dapat dipengaruhi 66 oleh etika auditor. Sehingga dapat disimpulkan bahwa semakin baik etika para auditor maka kinerja auditor akan semakin baik.

\section{DAFTAR PUSTAKA}

Andari, N. D., \& Nugraheni, R. (2016). Analisis Pengaruhmanajemen Waktu, Motivasi Kuliah, Dan Aktualisasi Diri Terhadap Prestasi Akademik Mahasiswa Yang Bekerja (Studi Padamahasiswa Jurusan Manajemen Fakultas Ekonomika Dan Bisnis Universitas Diponegoro Semarang). Diponegoro Journal Ofmanagement.

Arifah, D. A., \& Romadhon, C. (2015). Pengaruh Komitmen Organisasi, Komitmen Profesional Dan Gaya Kepemimpinan Terhadap Kepuasan Kerja Dengan Motivasi Sebagai Variabel Intervening. Journal Of Visual Languages \& Computing.

Arumsari, L. A. (2014). Pengaruh Profesionalisme Auditor, Independensi Auditor, Etika Profesi, Budaya Organisasi, Dan Gaya Kepemimpinan Terhadap Kinerja Auditor Pada Kantor Akuntan Publik Di Bali. E-Jurnal Akuntansi Universitas Udayana.

Astuti, E., Suhadak, E., Rahayu, S. M., \& Wilopo. (2018). The Influence Of Information Technology Strategy And Management Support To The Internal Business Process, Competitive Advantage, Financial And Non-Financial Performance Of The Company. International Journal Of Web Information Systems. Https://Doi.Org/10.1108/IJWIS-11-2017-0079

Darmawan, D. (2013). Prinsip-Prinsip Perilaku Organisasi. In Surabaya Pena Semesta.

Entuu, R. E. F., Sondakh, J. J., \& Ilat, V. (2013). Pengaruh Profesionalisme Auditor, Kualitas Audit, Etika Profesi Auditor, Dan Pengalaman Auditor Terhadap Pertimbangan Tingkat Materialitas Dalam Pemeriksaan Laporan Keuangan Pada Badan Pemeriksa Keuangan Republik Indonesia Perwakilan Sulawesi Utara. Jurnal Akuntansi.

Faisal, F., Situmorang, L. S., Achmad, T., \& Prastiwi, A. (2020). The Role Of Government Regulations In Enhancing Corporate Social Responsibility Disclosure And Firm Value. Journal Of Asian Finance, Economics And Business. Https://Doi.Org/10.13106/JAFEB.2020.VOL7.NO8.509

Gozali, E., Kamnis, S., \& Gu, S. (2013). Numerical Investigation Of Combustion And Liquid Feedstock In High Velocity Suspension Flame Spraying Process. Surface And Coatings Technology. Https://Doi.Org/10.1016/J.Surfcoat.2013.04.026

Futri, S., \& Juliarsa, G. (2014). Pengaruh Independensi, Profesionalisme, Tingkat Pendidikan, Etika Profesi, Pengalaman, Dan Kepuasan Kerja Auditor Terhadap Kualitas Audit Pada Kantor Akuntan Publik Di Bali. E-Jurnal Akuntansi. 
Halim, A. (2014). Anggaran Waktu Audit Dan Komitmen Profesional Sebaga Variabel Moderasi Pengaruh Kompetensi Dan Independensi Auditor Terhadap Kualitas Audit. Simposium Nasional Akuntansi XVII Lombok 2014.

Halim, A. (2015). Auditing 1 Dasar-Dasar Audit Laporan Keuangan. Auditing.

Hanna, E., \& Firnanti, F. (2013). Faktor-Faktor Yang Mempengaruhi Kinerja Auditor. Jurnal Bisnis Dan Akuntansi.

Hartidah, A. D., \& Ludigdo, U. (2010). Pengaruh Budaya Organisasi Terhadap Kinerja Auditor Pada Kantor Akuntan Publik Di Malang Dan Surabaya. Jurnal Akuntansi Multiparadigma. Https://Doi.Org/10.18202/Jamal.2010.08.7090

Hasibuan, M. S. P. (2011). Manajemen Sumber Daya Manusia. Edisi Revisi Jakarta: Bumi Aksara.

Kreitner Dan Kinicki .Bruno, L. (2010). Pengaruh Pengalaman, Kompetensi Profesional, Kecerdasan Intelektual, Dan Komitmen Organisasi Terhadap Kinerja Auditor (Studi Empiris Pada Kantor Akuntan Publik Di Wilayah Jakarta Barat Dan Jakarta Selatan). Journal Of Chemical Information And Modeling.

Kusumastuti, R. D. (2008). Pengaruh Pengalaman, Komitmen Profesional, Etika Organisasi Dan Gender Terhadap Pengambilan Keputusan Etis Auditor Pada Auditor Kantor Akuntan Publik Di Jakarta. In Fakultas Ekonomi Dan Ilmu Sosial UIN Syarif Hidayatullah Jakarta.

Ningsih, F., \& Nadirsyah. (2017). Pengaruh Independensi, Skeptisisme Profesional Auditor, Penerapan Standar Audit, Dan Etika Audit Terhadap Kualitas Hasil Audit (Studi Pada Auditor BPK RI Perwakilan Provinsi Aceh). Jurnal Ilmiah Mahasiswa Ekonomi Akuntansi.

Novaria, R., \& Istijanto, S. (2018). Optimizing The Potential Places And Attractions Of Tourist Destination. The Social Sciences.

Nugraha, I. B. S. A., \& Ramantha, I. Wayan. (2015). Pengaruh Profesionalisme, Etika Profesi Dan. E-Jurnal Akuntansi Universitas Udayana.

Nursal, D. G. A., Tamela, P., \& Fitrayeni, F. (2017). Faktor Risiko Kejadian Preeklampsia Pada Ibu Hamil Di Rsup Dr. M. Djamil Padang Tahun 2014. Jurnal Kesehatan Masyarakat Andalas. Https://Doi.Org/10.24893/Jkma.V10i1.161

Mukoffi, A. (2019). Kualitas audit terhadap mutu laporanKEUANGAN. JAMSWAP, 4(4), 26-34.

Mcinnes, L., Healy, J., \& Astels, S. (2017). Hdbscan: Hierarchical Density Based Clustering. The Journal Of Open Source Software. Https://Doi.Org/10.21105/Joss.00205

Pangesti, S.N., Rahayu, S. (2017). Pengaruh Komitmen Profesional Dan Sosialisasi Antisipatif Mahasiswa Akuntansi Terhadap Whistleblowing (Studi Empiris Pada Mahasiswa Akuntansi Universitas Telkom Di Bandung Tahun Akademik 2015/2016). E-Proceeding Og Management.

Pengaruh Etika Auditor, Pengalaman Auditor, Fee Audit, Dan Motivasi Auditor Terhadap Kualitas Audit (Studi Pada Auditor KAP Di Semarang). (2014). Diponegoro Journal Of Accounting.

Prabayanthi, P. A., \& Widhiyani, N. L. S. (2018). Pengaruh Profesionalisme, Budaya Organisasi Dan Komitmen Organisasi Pada Kinerja Auditor. EJurnal Akuntansi. Https://Doi.Org/10.24843/Eja.2018.V22.I02.P09

Pratama, I. G. P. A. R., \& Latrini, N. M. Y. (2016). Kemampuan Komitmen Profesional Memoderasi Pengaruh Kompleksitas Tugas Dan Konflik Peran 
Pada Kinerja Auditor. E-Jurnal Akuntansi Universitas Udayana.14.3.

Primaraharjo, B., \& Handoko, J. (2011). Pengaruh Kode Etik Profesi Akuntan Publik Terhadap Kualitas Audit Auditor Independen Di Surabaya. Jurnal Akuntansi Kontemporer. Https://Doi.Org/10.33508/Jako.V3i1.1013

Robins, Stephen. P. (2014). Teori Budaya Organisasi. In Perilaku Organisasi.

Safitri, D. (2014). Pengaruh Independensi Auditor Dan Gaya Kepemimpinan Terhadap Kinerja Auditor Dengan Komitmen Organisasi Sebagai Variabel Intervening. Jurnal Ilmiah Ekonomi Dan Bisnis.

Sitio, R., \& Anisykurlillah, I. (2014). Pengaruh Pemahaman Good Governance, Gaya Kepemimpinan, Budaya Organisai Dan Struktur Audit Terhadap Kinerja Auditor. Accounting Analysis Journal.

Sugiyono. (2013). Metode Penelitian Pendidikan Pendekatan Kuantitaif, Kualitatif, Dan R\&Dsugiyono. 2013. "Metode Penelitian Pendidikan Pendekatan Kuantitaif, Kualitatif, Dan R\&D." Metode Penelitian Pendidikan Pendekatan Kuantitaif, Kualitatif, Dan R\&D. Https://Doi.Org/10.1. In Metode Penelitian Pendidikan Pendekatan Kuantitaif, Kualitatif, Dan R\&D.

Tarigan, M. U., \& Susanti, P. B. (2013). Pengaruh Kompetensi, Etika, Dan Fee Audit Terhadap Kulaitas Audit. Jurnal Akuntansi.

Trisnaningsih, S. (2007). Independensi Auditor Dan Komitmen Organisasi Sebagai Mediasi Pengaruh Pemahaman. Independensi Auditor Dan Komitmen Organisasi Sebagai Mediasi Pengaruh Pemahaman Good Governance, Gaya Kepemimpinan Dan Budaya Organisasi Terhadap Kinerja Auditor.

Tafqihan, Z., \& Suryanto, S. (2014). Pengaruh Kompetensi Guru Terhadap Komitmen Profesional Dan Dampaknya Pada Kinerja Serta Kepuasan Kerja Guru Matematika Smp Dan MTS. Jurnal Riset Pendidikan Matematika. Https://Doi.Org/10.21831/Jrpm.V1i2.2682

Robins, Stephen. P. (2014). Teori Budaya Organisasi. In Perilaku Organisasi.

Wibowo, D. S. (2016). Analisis Faktor Kompetensi Dan Motivasi Kerja Dalam Membentuk Sikap Kerja Profesional. Insight: Jurnal Pemikiran Dan Penelitian Psikologi. Https://Doi.Org/10.32528/Ins.V10i2.300

Widarsono, A., \& Oktarina, M. (2015). Pengaruh Locus Of Control Dan Komitmen Profesional Terhadap Kinerja Auditor Internal. Jurnal Riset Akuntansi Dan Keuangan. Https://Doi.Org/10.17509/Jrak.V3i2.6614

Widowati, M., \& Mohklas. (2015). Model Kepuasan Pelanggan Dengan Pengalaman Kerja Sebagai Variabel Moderating (Studi Pada Rumah Sakit Di Kota Semarang). Fokus Ekonomi.

Wonosardono, A. A. (2018). Pengaruh Gaya Kepemimpinan, Budaya Organisasi, Etika Profesi, Motivasi Kerja, Struktur Audit, Dan Ketidakjelasan Peran Terhadap Kinerja Auditor. Fti Umn.

Yudhistira, R. A. (2016). Pengaruh Budaya Organisasi, Komitmen Profesional Auditor, Dan Tingkat Religiusitas Auditor Terhadap Pertimbangan Etis Auditor Pada Kantor Akuntan Publik Di Surabaya. In Jurnal Akuntansi.

Saufins, G. M. (2020). Pengaruh Kecedarsana Intelektual, Dan Etika Auditor Terhadap Kinerja Auditor Dengan Penggunaan Teknologi Informasi Sebagai Model Intervening (Doctoral Disertation, Universitas Negeri Jakarta).

Pramudyawati, K. (2019). Pengaruh Independensi, Kinerja Profesi Auditor, Dan Komitmen Orgsnisasi Terhadap Kinerja Auditor (Studi Empiris Pada Kantor Akuntan Publik Di Surakarta Dan Semarang) (Doctoral Dissertation, Universitas Muhammadiyah Surakarta). 
Zaenudin, J. (2017). Pengaruh Etika Profesi Auditor Dan Pengalaman Auditor Terhadap Kinerja Auditor (Penelitian Pada Kantor Akuntan Publik (KAP) Di Kota Bandungyang Terdaftar Di BPK RI) (Doctoral Dissertation, Universitas Komputer Indonesia).

Cahyani, K. C. D., Purnawati, I. G. A., Herawati, N. T., \& AK, S. 2015. Pengaruh Etika Profesi Auditor, Profesionalisme, Motivasi, Budaya Kerja, Dan Tingkat Pendidikan Terhadap Kinerja Auditor Junior (Studi Empiris Pada Kantor Akuntan Publik Di Bali). JIMAT (Jurnal Ilmiah Mahasiswa Akuntansi) Undiksha, 3(1).

Fadhilah, N. Pengaruh Komitmen Organisasi Dan Komitmen Profesional Terhadap Kinerja Auditor Serta Dampaknya Kepada Kualitas Organisasi (Studi Empiris Pada Kantor Akuntan Publik Di Jakarta) (Bachelor's Thesis, Jakarta: Fakultas Ekonomi Dan Bisnis UIN Syarif Hidayatullah).

Priesty, D. A. A. D., \& Budiartha, I. K. (2017). Pengaruh Etika Profesi Dan Komitmen Profesional Auditor Terhadap Kinerja Auditor Dengan Skeptisisme Profesional Sebagai Pemediasi. E-Jurnal Akuntansi, 20(2), 1162-1188.

Temaja, I. P. E. A. W.,\& Utama, I. M. K. (2016). Pengaruh Profesionalisme, Kepribadian Hardiness, Motivasi Dan Budaya Organisasi Pada Kinerja Auditor Di Kantor Akuntan Publik. E-Jurnal Akuntansi, 15(3), 1711-1739.

Prabayanthi, P. A., \& Widhiyani, N. L. S. (2018). Pengaruh Profesionalisme, Budaya Organisasi Dan Komitmen Organissi Pada Kinerja Auditor. E-Jurnal Akuntansi, 22(2), 1059-1084.

Hanna, E., \& Firnanti, F. (2013). Faktor-Faktor Yang Mempengaruhi Kinerja Auditor. Jurnal Bisnis Dan Akuntansi, 15(1), 13-28.

Hartidah, A. D., \& Ludigdo, U. (2010). Pengaruh Budaya Organisasi Terhadap Kinerja Auditor Pada Kantor Akuntan Publik Di Malang Dan Surabaya. Jurnal Akuntansi Multiparadigma, 1(2), 239-253. 